\title{
Holistic methods of foreign-language instruction as precursors of a renewed interest in the theatre arts for language teaching Udo O.H. Jung
}

\begin{abstract}
During the last fifteen years new methods of teaching have been introduced to the foreign language teacher who was raised on an audiolingual diet. These teachers prefer teaching to learning, because teaching a subject in accordance with acknowledged tricks of the trade is what teachers are there for. Unfortunately, words such as teaching, learning and method have been semantically disappropriated during the period of change. The audiolinguist conceived teaching as a series of steps anchored in the logic of behaviourism, while to the methodologist of today teaching seems to be more or less identical with waiting for learning to happen. The author gives brief descriptions of some methodologies, establishes the metaphor of theatre arts as a suitable denominator for all holistic methods and presents arguments in favour of a revival of the theatre arts as a means of promoting foreign language learning.
\end{abstract}

Gedurende die laaste vyftien jaar is verskeie nuwe metodes vir die aanleer van vreemde tale bekendgestel. Vir die onderwyser in vreemde tale wat nog opgegroei het in 'n oudiolinguale atmosfeer is dit uiteraard vreemd. Hierdie onderwysers het nog onderrig verkies eerder as aanleer. Die onderrig van ' $n$ vak in ooreenstemming met erkende kunsgrepe is immers waarvoor onderwysers daar is. Gedurende die periode van verandering is daar egter op semantiese vlak 'n vraagteken geplaas oor woorde soos "onderrig", "aanleer" en "metode". Vir die oudiolinguis is onderrig 'n reeks stappe wat vloei uit die logika van die behaviorisme, terwyl die metodoloog van vandag onderrig eerder sien as 'n wagproses op leer om te gebeur. Die outeur gee kort beskrywings van sekere metodes, hy beklemtoon die uitvoerende kunste as toepaslike gemene deler vir alle holistiese metodes en hy bepleit ' $n$ herlewing van die teaterkunste as 'n manier om die aanleer van vreemde tale te bevorder.

\section{Introduction}

During the last fifteen years or so, new methods of foreign-language instruction have almost imperceptibly crept upon the foreign-language teacher who was raised on an audiolingual diet. Their common credo is the subservience of teaching to learning. This may sound commonplace and self-evident; after all, teaching a subject in accordance with the acknowledged "tricks" of the trade so that pupils may easily identify, process and store the information presented, is what the teacher is there for. Unfortunately, words like "teaching", "learning" and "method" have been semantically disappropriated during this period of change. True, it is not unusual for words to be situated on a cline: the audiolingualist conceived of teaching as a series of steps anchored in the logic of behaviourism, whereas to the fringe methodologist of today teaching seems to be more or less identical with waiting for learning to happen. But one has to 
be aware of the possibility of such a slow depletion of words, in order not to be deceived by them. As long as teaching and method are conceived of as dependent variables, with a theory of learning or acquiring language as the point of departure, discredit to the learning theory entails that of its satellite methods.

The classic case is Chomsky's review of Skinner's Verbal Behavior in 1959. The linguist demonstrated to the behaviourist that the latter's conception of how language is acquired under normal (i.e. untutored) circumstances was invalid. Because of their assumed unconditional interrelatedness both learning theory and teaching method collapsed and nothing was placed in their stead. Once the theoretical props were gone, "learning" relapsed into chaos, and teaching became almost meaningless. With teachers afraid of asserting themselves the learners moved further up-stage. They advanced to the centre of interest and became the primary focus of language acquisition research.

Although an enormous amount of time, money and intellectual effort (Brown 1973; Dulay, Burt and Krashen 1982; Felix 1980; Felix 1982; Hatch 1978; Wode 1981) has been invested. since the late 1960's the results obtained so far have not carried enough conviction to bring about another paradigm change. At the same time people like Charles A. Curran (Counseling-Learning), Caleb Gattegno (The Silent Way), Georgi Lozanov (Suggestopedia) and J.J. Asher (Total Physical Response) started filling the void left by research, or the lack of it, rather, with unconventional ideas of their own on how foreign languages should be taught. In what follows I shall give brief descriptions of these fringe methodologies, establish the metaphor of histrionics or theatre arts as a suitable common denominator for all holistic methods and present arguments in favour of a revival of the theatre arts as a means of promoting foreign. language learning.

\section{Holistic methods of foreign-language teaching}

The word "holistic" is derived from the Greek word "holos", meaning "whole", wherefore some people spell it as "wholistic". The idea is that the process of learning must involve the learner as a totality, an ensemble of intellect, volition and emotion. Relatively short descriptions of how the various methods aim at total learning are in order here, because the aim is not to proselytize, but to argue that alternative methods should be seen as stepping stones on the way to a personality-shaping technique of great value: theatrical performances in the foreign-language class.

\subsection{Suggestopedia}

Georgi Lozanov, a Bulgarian psychiatrist, who has laid down the principles of Suggestopedia in his authoritative Suggestology and Outlines of Suggestopedy (1978), conceives of man as consisting of two planes. The surface plane is what language teachers normally address themselves to. Below the surface lies a vast reservoir of learning potential which must be tapped. In order to do this students entering a language class assume surrogate identities: they become Dr. Morgan or Miss Pringle, "masks", as Earl Stevick (1980) says, "to hide behind" (236). This helps them to cast off their everyday personalities with all the incumbent norms of society which hold learning back. Once the protective mail people tend to surround themselves with has been discarded by means of "desuggestion" the learner is open to suggestions by the teacher that he can learn faster and memorize better than previously assumed.

\subsection{The silent way}

To describe what the thinking of Caleb Gattegno, inventor of The Silent Way, is about, Stevick (1980) comes up with the following: "In Gattegno's view, as I have read him, the Actor is the Self, the Stage is the whole world outside the Self, and the Play is limited in Time" (37). On the level of actual technique this philosophical credo manifests itself in a teacher who remains silent most of the time. His job is to tease out the student's learning capacity. To put it the other way round: "the teacher is potentially very useful, but is not absolutely necessary" (Stevick 1980:45). He may place a handful of coloured rods on the table, to begin with, pick one out, motion to the students to be silent, pronounce the foreign word associated with the 
object once and direct the students to repeat. The important thing here is that the content of pieces, that the teacher refrains from ostensibly reinforcing correct answers so that the student gets a "feel" for when he is right or wrong, that, in other words, he gains self-confidence and learns to trust himself.

\subsection{Community language learning (CLL)}

Charles Curran, the o:iginator of Community Language Learning, calls his technique a "whole-person model". The community of learners/clients sit in a circle facing each other, whereas the teacher/counsellor remains outside. The students in the circle are allowed to say whatever comes to mind in their native language, whereupon the counsellor provides the target equivalents for imitation/repetition. As a rule, the target-language utterances are recorded for later inspection. It is hoped that the learners do not look upon what they say as verbal chains only; instead the teacher takes great care (this includes the way he dresses) to ensure that his clientele looks upon learning as persons or, as one put it, "that the skeleton (bare bones grammar) of a new language is loveable only when encased in a warm bodyfirst, in that of the teacher-counsellor and then, as the learners grow in linguistic independence and peer interdependence, in the body of the learning community" (Dutra 1980:144).

\subsection{Total physical response}

The method of Total Physical Response is the invention of the psychologist J.J. Asher. It does what it says: Teachers give commands in the foreign language, students execute these commands, i.e. they respond physically by e.g. writing the word "Luke" on the board in response to the teacher's "Luke, walk to the door! When Luke walks to the door, Maria will write Luke's name on the chalkboard." In this instance, the teaching aim obviously is the simple future of English verbs. The rationale behind this technique is the assumption that learning a language involves, should involve both body and mind. Students and teachers alike perform the actions described by the verbal expressions.

\section{A metaphor for holistic teaching methods}

Earl Stevick, an expert on holistic, sometimes called humanistic teaching methods (The BritBritish Council 1982), has done much to popularize these approaches. His Teaching languages - a way and ways is the locus classicus of the alternative movements. In describing the brainchildren of Lozanov, Gattegno and Curran (for some unknown reason J.J. Asher was excluded) Stevick frequently, but maybe unconsciously, reverts to the word "trick" when method is what he means. It might be insightful to count the frequency of occurrence of this lexical item throughout the more than 300 pages the book consists of. I should also like to submit that if a metaphor was needed for the four holistic methods just described theatre would do (on the concept of metaphor in foreign-language teaching methodology see Nattinger 1984).

In a readable article Mumeo Yoshikawa has pointed out that despite glaring surface dissimilarities between, say, The Silent Way and Total Physical Response, an undercurrent of shared convictions binds all holistic methods together: "... what is considered essential and crucial may be viewed not so much as a specific method or technique per se, but as a real understanding of the new perspective on a holistic individual. Without understanding this assumption of the holistic individual as essentially an active, voluntary, responsible, self-motivating, relational, autonomous, and free being, mere methodologies or techniques are reduced to artificial and mechanical schemes that fail to be meaningful" (Yoshikawa 1982:394). John Norrish, in a recent survey article, has arrived at the same conclusion: "Perhaps the most obvious common factor in all three methodologies is that in all of them, the learner is regarded as central to the process" (Norrish 1985:13). Of course, he is, and one might even venture to say that the silent teacher who merely presents the matter and waits for learning to occur is the epitome of the new wave.

It is this element of distrust of both teacher and method and a preference for "tricks" in order to heal the student personality which is normally split into conscious and unconscious, body and 
mind, and to make him whole again, which makes me suggest that theatre is the right metaphor and the right method to bring about this reintegration. In the words of Susan Stern: "Drama techniques restore the body and emotions to language learning, thereby restoring motivation" (Stern 1981:79). And the foreignlanguage teacher who role-plays with the students in his beginners class already holds Ariadne's thread to creative dramatics in his hands. All he has to do is to wind it up and, to borrow from Andrew Marvell, roll it into one ball.

\section{From role-play to creative dramatics to commu- nicative competence}

Books on role-play are legion (e.g. Kleppin 1980; Lee 1965; Maley and Duff 1978). Roleplay is the icing on the grammatical exercise cake which represents the bulk of all classroom activities. Traditionally, the role of role-playing here is to loosen the students' tongues, to oil their articulatory machinery and to increase motivation by driving the rule-governed aspect of language learning to the far end of consciousness. Those who, unlike Stephen Krashen, believe in the interpenetrability of the two systems which according to him constitute man's language learning capacity, would maintain that the business of role-playing is to bridge the gulf that separates acquisition from learning.

Role-playing is the closest one can hope to get to real-life situations. As Morry van Ments says in a recent monograph: "... the 'acting out' in role-playing is, for all practical purposes, no greater than that which is done by the majority of people from time to time in the course of their everyday lives" (20). At the same time van Ments deplores "the unfortunate confusion between role-playing and acting" (19) insisting that the essential difference between the two is "that acting consists of bringing to life a dramatist's ideas (or one's own ideas) in order to influence and entertain an audience, whereas role-play is the experiencing of a problem under an unfamiliar set of constraints in order that one's own ideas may emerge and one's understanding increase" (19). Such a definition unwittingly pays homage to the high degree of similarity between role-play and acting, for an unsophisticated spectator is usually unable to tell the one from the other. If one looks upon role-play as an element in mother-tongue teaching or in connection with second-language acquisition as distinct from foreign-language learning, role-play is indeed an extension of everyday life. But look at role-play from the vantage point of the foreign-language teacher and the differences come to light immediately. Encapsulated in foreign-language role-play is a strong histrionic element. In its early phases role-playing in a foreign-language class is a theatrical performance: students learn dialogue parts by heart and act them out in front of their classmates with imaginary backdrops of zoos, restaurants and surgeries behind them. If expressions of self intrude in such play-acting, there is always the danger of cross-cultural interference or negative transfer from source culture behavioural patterns.

A student who reproduces a professional playwright's words is closer to the foreign culture than the one who merely uses a foreign idiom to express roles which are part of the social environment he was brought up in. An American daddy looks and behaves differently from his Japanese counterpart, and the Japanese student of English as a foreign language who is called in front of a crowd of $\mathbf{3 0}$ or more classmates will gratefully tall back on the wordage provided by course book or actor's cue card.

Admittedly, it is a long way from play-acting/ role-playing to creatively using a foreign idiom; more often than not such a feat is achieved only after an extensive stay in the country where the language is spoken. But there can be no question that Erminio G. Neglia is right when he says about play-acting: "Students are asked to project themselves into the roles of native speakers in a staged second-language environment" (694). And he is also right about the way eventual success is achieved: "Countless drills on pronunciation and intonation have made them, /the student/ perhaps for the first time in their college life, as fluent and confident in their command of the language (although limited to the dramatic dialogues and situations of the plays) as native speakers" (696).

But are they really limited to the dramatic dialogues and situations of the plays? 
"Limited" would seem to be the wrong tag in connection with dramatic dialogues. Only in a very narrow sense are students limited to the syntactic and lexical choices made for them by the playwright. The characters they impersonate live a richer life than most of us; they hate and love more intensively than those in the pit; their (stage) lives are spent within two to three hours. The actors are bound to profit spiritually from the characters in the play.

And as far as the psy hholinguistic side is concerned, Susan L. Stern has established that drama facilitates communication among $\mathrm{L} 2$ learners. She hypothesized that heightened selfesteem, motivation to learn and spontaneity as well as an increased capacity for empathy and a lowered sensitivity to rejection would result from active participation in creative drama. These factors in turn tend to facilitate communication so that it can be said with no small amount of confidence that creative dramatics are a spiritually rewarding detour to communicative competence, which is the first aim of all foreign-language teaching.

\section{Bibliography}

ASHER, J.J. 1979. Learning another language through actions. Los Gatos, CA: Sky Oaks Productions.

THE BRITISH COUNCIL (ed.) 1982. ELT documents 113-Humanistic approaches: an empirical view. London: The British Council.

BROWN, R. 1973. A first language. Cambridge, MA: Harvard University Press.

CHOMSKY, N. 1959. Review of B.F. Skinner's "Verbal Behavior". Language 35.

CURRAN, C.A. 1972. Counseling-Learning. A whole-person model for education. New York: Grune Stratton.

DULAY, H., BURT, M. \& KRASHEN, S. 1982. Language two. New York: Oxford University Press.
DUTRA, I. 1980. A roller coaster ride to Swahili-land, or nobody loves a skeleton. Stevick, E.W. Teaching languages-a way and ways. Rowley, MA: Newbury House.

FELIX, S.W. (ed.) 1980. Second language development. Trends and issues. Tübingen: Gunter Narr Verlag.

FELIX, S.W. 1982. Psycholinguistische Aspekte des $Z$ weitsprachenerwerbs. Tübingen: Gunter Narr Verlag.

GATTEGNO, C. 1970. The common sense of teaching foreign languages. New York: Educational Solutions.

HATCH, E. (ed.) 1978. Second language acquisition. Rowley, MA: Newbury House.

HOLDEN, S. 1981. Drama in language teaching. London: Longman.

JUNG, U.O.H. (In press). Holistische Methoden fremdsprachlicher Unterweisung als Wegbereiter des neuen Schülertheaters. Eine Auswahlbibliographie. Die Neueren Sprachen.

KLEPPIN, K. 1980. Das Sprachlernspiel im Fremdsprachenunterricht. Untersuchungen zum Lehrer- und Lernverhalten in Sprachlernspielen. Tübingen: Gunter Narr Verlag.

KRASHEN, S.D. 1982. Principles and practice in second language acquisition. Oxford: Pergamon.

LEE, W.R. 1965. Language-teaching games and contests. Oxford: Oxford University Press.

LOZANOV, G. 1978. Suggestology and outlines of Suggestopedy. New York: Gordon and Breach.

MALEY, A. \& DUFF, A. 1978. Drama techniques in language learning. Cambridge: Cambridge University Press. 
NATTINGER, J.R. 1984. Communicative language teaching: a new metaphor. TESOL Quarterly 18.

NEGLIA, E.G. 1982. A dramatic approach to theatre and language learning. The Canadian Modern Language Review 38.

NORRISH, J. 1985. Current approaches to the teaching of English as a foreign language-alternative methods. Zielsprache English 15.

SMITH, S. 1983. The theater arts and the teaching of second languages. Reading, MA: Addison-Wesley.

STERN, S.L. 1981. Drama in second language learning from a psycholinguistic perspective. Language Learning 30.
STEVICK, E.W. 1980. Teaching languages-a way and ways. Reading, MA: Newbury House.

VAN MENTS, M. 1983. The effective use of role-play. A handbook for teachers and trainers.

London: Kogan Page.

VIA, R.A. 1976. English in three acts. Honolulu, HI: East-West Center.

WODE, H. 1981. Learning a second language. An integrated view of language acquisition. Tübingen: Gunter Narr Verlag.

YOSHIKAWA, M. 1982. Language teaching methodologies and the nature of the individual: a new definition. The Modern Language Journal 66.

It is the darling delusion of mankind that the world is progressive in religion, toleration, freedom, as it is progressive in machinery.

The style of an author should be the image of his mind, but the choice and command of language is the fruit of exercise. 